\title{
Contributions of Climate Change and Human Activities on Runoff Variations in the Central Part of Tajikistan in Central Asia
}

\author{
Nekruz Gulahmadov $^{1}$, Yaning Chen ${ }^{2}$, Aminjon Gulakhmadov ${ }^{1}$, Moldir Rakhimova ${ }^{1}$, and \\ Manuchekhr Gulakhmadov ${ }^{1}$ \\ ${ }^{1}$ Xinjiang Institute of Ecology and Geography \\ ${ }^{2}$ The Chinese Academy of Sciences
}

February 10, 2021

\begin{abstract}
Comprehensive studies of the contributions of climate variation and anthropogenic activities to runoff alterations are essential for sustainable management of water resources in Central Asian countries. In the Kofarnihon River Basin (KRB) in Central Asia, both changing climate conditions and anthropogenic activities are known to have caused variations to the hydrological cycle. Therefore, quantifying the net influence of human contribution to the runoff changes is a challenge. In this study, by applying the original and modified Mann-Kendall trend test, Pettitt test, double cumulative curve and elasticity methods the historical trends and breakpoint changes of the hydro-climatic variables including temperature, precipitation, potential evapotranspiration, and runoff over the 1950-2016 along were determined, in addition the contributions of climate variation and anthropogenic activities to runoff changes in the KRB were evaluated. The trend analysis exhibited a significant increasing trend in annual temperature and potential evapotranspiration and the annual precipitation trend showed insignificant decreasing trend during the 1950-2016 time period. The breakpoint change was detected in runoff occurs in 1991. Further, the time series (1950-2016) are separated into the prior impacted period (1950-1991) and post impacted period (1992-2016) with trend test. The results showed that anthropogenic activities played a dominant role in changes in the runoff with a contribution of $79.94 \%$ in the upstream and $97.78 \%$ in the downstream of the KRB. Climate change contributed to $20.06 \%$ in the upstream and $7.53 \%$ in the downstream of the catchment during the post impacted period. In the land-use type changes, the dominant role played construction land which showed that the area from $248.63 \mathrm{~km} 2$ in 1990 increased to $685.45 \mathrm{~km} 2(175.69 \%)$ in 2015 . The findings suggest that it is essential to adopt effective steps for sustainable development of ecological, hydrological and social order in the KRB in Central Asia.
\end{abstract}

\section{Hosted file}

Manuscript.pdf available at https://authorea.com/users/394884/articles/508218-contributionsof-climate-change-and-human-activities-on-runoff-variations-in-the-central-part-oftajikistan-in-central-asia

\section{Hosted file}

FIGURE 1.pdf available at https://authorea.com/users/394884/articles/508218-contributionsof-climate-change-and-human-activities-on-runoff-variations-in-the-central-part-oftajikistan-in-central-asia

\section{Hosted file}

FIGURE 2.pdf available at https://authorea.com/users/394884/articles/508218-contributionsof-climate-change-and-human-activities-on-runoff-variations-in-the-central-part-oftajikistan-in-central-asia 


\section{Hosted file}

FIGURE 3.pdf available at https://authorea.com/users/394884/articles/508218-contributionsof-climate-change-and-human-activities-on-runoff-variations-in-the-central-part-oftajikistan-in-central-asia

\section{Hosted file}

FIGURE 4.pdf available at https://authorea.com/users/394884/articles/508218-contributionsof-climate-change-and-human-activities-on-runoff-variations-in-the-central-part-oftajikistan-in-central-asia

\section{Hosted file}

FIGURE 5.pdf available at https://authorea.com/users/394884/articles/508218-contributionsof-climate-change-and-human-activities-on-runoff-variations-in-the-central-part-oftajikistan-in-central-asia

\section{Hosted file}

FIGURE 6.pdf available at https://authorea.com/users/394884/articles/508218-contributionsof-climate-change-and-human-activities-on-runoff-variations-in-the-central-part-oftajikistan-in-central-asia

\section{Hosted file}

FIGURE 7.pdf available at https://authorea.com/users/394884/articles/508218-contributionsof-climate-change-and-human-activities-on-runoff-variations-in-the-central-part-oftajikistan-in-central-asia

\section{Hosted file}

TABLE 1.pdf available at https://authorea.com/users/394884/articles/508218-contributionsof-climate-change-and-human-activities-on-runoff-variations-in-the-central-part-oftajikistan-in-central-asia

\section{Hosted file}

TABLE 2.pdf available at https://authorea.com/users/394884/articles/508218-contributionsof-climate-change-and-human-activities-on-runoff-variations-in-the-central-part-oftajikistan-in-central-asia

\section{Hosted file}

TABLE 3.pdf available at https://authorea.com/users/394884/articles/508218-contributionsof-climate-change-and-human-activities-on-runoff-variations-in-the-central-part-oftajikistan-in-central-asia

\section{Hosted file}

TABLE 4.pdf available at https://authorea.com/users/394884/articles/508218-contributionsof-climate-change-and-human-activities-on-runoff-variations-in-the-central-part-oftajikistan-in-central-asia

\section{Hosted file}

TABLE 5.pdf available at https://authorea.com/users/394884/articles/508218-contributionsof-climate-change-and-human-activities-on-runoff-variations-in-the-central-part-oftajikistan-in-central-asia

\section{Hosted file}


TABLE 6.pdf available at https://authorea.com/users/394884/articles/508218-contributionsof-climate-change-and-human-activities-on-runoff-variations-in-the-central-part-oftajikistan-in-central-asia 